\title{
Conclusion: Regional Parliaments - A Distinct Role in the EU?
}

Anna-Lena Högenauer, Gabriele Abels

This is the author pre-print version. The final version has been published in the Journal of Legislative Studies, Vol. 23, issue 2

Abstract:

Regional parliaments can today try to shape EU policy-making via a range of domestic and European channels. In the context of a renewed interest in the subnational level, this article aims to address three core questions: Have regional parliaments really been empowered by the EWS provisions? Which factors explain differences in strength and mobilization? Finally, what kind of a role do regional parliaments play in EU policy-making today, now that they have had several years to react to the trend towards multi-level parliamentarism? The article argues that regional parliaments do indeed have the potential to contribute a distinct perspective to EU policy-making, even if their current level of activity is still low. It distinguishes six particularly important factors contributing to the empowerment and mobilization of regional parliaments: whether the new powers are formally protected, the previous constitutional strength of the regional parliament, the absence of second chambers that represent regional governments, good executive-legislative cooperation, resources and experience.

\section{Introduction}

In the introduction to this volume, author1 argued that the European Union suffered from a democratic deficit (author 1, this volume): On the one hand, European integration encouraged a trend towards deparliamentarization and executive decision-making. Until the 1990s, the shifting of competences to the European level meant that national and regional parliaments lost legislative powers, whereas national governments collectively formed the main legislative body on the European level. At the same time, the European Parliament (EP) - as the only directly elected institution on the European level - had only consultative or limited legislative and scrutiny powers. On the other hand, when re-parliamentarization finally set in, it focused primarily on the empowerment of the European Parliament. However, the low electoral turnout at EP elections jeopardizes the ability of the EP to legitimize EU policy-making. In addition, the legitimizing function of national parliaments was first acknowledged with the Maastricht Treaty. Ever since then, the role of national parliaments was strengthened, last but not least with the Lisbon Treaty, which emphasizes the involvement of national parliaments in EU decision-making, especially via the new 
system of subsidiarity control ('Early Warning System', EWS), and the need for inter-parliamentary cooperation between the EP and national parliaments.

This increasing focus on national parliaments reflects the fact that Europe still consists of multiple demoi rather than one cohesive demos (Nicolaïdis, 2013; Cheneval and Schimmelfenning, 2013). Yet, was is too often neglected is the fact that the Lisbon Treaty has conferred also on parliaments of legislative regions the right to participate in the EWS and the political dialogue with the European Commission (cf. Vara Arribas and Högenauer, 2015). These new tools provide also regional parliaments with a control function on the European level, but arguably also with the opportunity to push for substantive change. Kiiver (2012), in particular, argues that parliaments often use reasoned opinions in the EWS to propose substantive changes, thus trying to compensate for their former legislative function in these policy areas. In addition to these new tools, just as national parliaments also regional ones have at their disposal a set of traditional instruments of oversight over their government, such as parliamentary questions, plenary debates, resolutions and, in some cases, mandates. However, in the case of regional parliaments - which are the focus of this volume instruments of oversight are weakened in their effectiveness by the fact that the regional governments themselves usually only have a very indirect influence on EU policy-making, e.g. via the coordination of the member state's position.

As regional parliaments can today try to shape EU policy-making via a range of different instruments, this volume has tried to address three core questions: Have regional parliaments really been empowered by the EWS provisions? Given the fact that current studies of regional parliaments suggest that they diverge in their strength and level of activity (e.g. Boronska-Hryniewiecka, 2013; Abels and Eppler, 2015), the question is which factors explain those differences. Finally, what kind of a role do regional parliaments play in EU policy-making today, now that they have had several years to react to the trend towards multi-level parliamentarism? In the following sections, each of these questions will be discussed in the light of the contributions to this volume.

\section{A new empowerment of regional parliaments?}

Prior to the debates surrounding the failed Treaty establishing a Constitution for Europe, regional parliaments were all but invisible in EU politics. Their only direct connection to the European institutions was via the Committee of the Regions (CoR), where they were a small minority, making up roughly 10 percent of its members (Högenauer, 2015). At home, they could control their regional governments via traditional forms of scrutiny, while facing the challenge that their regional government itself had usually only an indirect impact on EU policy-making. The creation of the EWS 
represented an important symbolic change, as it provided regional parliaments with legislative powers with an important channel of communication with the European level and potentially strengthened their role in the domestic arena.

In the introduction to this volume, Author 1 (this volume) expected the EWS to have only a modest direct impact on the strength of these regional parliaments: They can adopt a reasoned opinion to declare a European legislative proposal to be in breach of the principle of subsidiarity, but reasoned opinions are not binding on the European institutions. In addition, in most cases, regional reasoned opinions are not sent directly to the European Commission, but to the national parliament (or a chamber thereof), which then decides whether to adopt a reasoned opinion or not. The regional voices are thus often mediated by national parliaments (Vara Arribas, 2015). Further weaknesses and obstacles include the short timeframe within which reasoned opinions have to be submitted, the high volume of EU legislation, the scarcity of resources, disagreements about the meaning of 'subsidiarity' and a lack of interest on the part of regional parliamentarians (Abels, 2015a: 27-36; Schmitt et al., 2013; Schneider et al., 2014). However, based on the literature on national parliaments (e.g. Gattermann et al., 2015; Hefftler and Gattermann, 2015), Author 1 (this volume) also expected the EWS to indirectly empower regional parliaments by triggering internal reforms that allowed them to react to EU affairs faster and more effectively.

In the contribution to this volume, Author 2 (this volume) argues that the EWS did indeed empower regional parliaments - both directly and indirectly. S/he defines 'regional empowerment' as 'an increased capacity of regional authorities to influence public policy decisions through their involvement in the policy-making process which, ideally, should translate into co-responsibility for governance, awareness of its costs and improvement of its effectiveness'. More specifically Author 2 (this volume) distinguishes five dimensions of regional empowerment that are all present in the case of the EWS. Firstly, regional parliaments benefit from institutional empowerment where member states adopt formal rules or inter-institutional agreements on regional parliamentary involvement in the EWS. Secondly, if their recommendations are taken on board, regional parliaments benefit from policy empowerment. Thirdly, a rising level of activity on the part of regional parliaments and an increased willingness to acknowledge their views by other institutions would result in political empowerment. Fourthly, where regional parliaments obtain better access to EU documents, they experience information empowerment. Finally, if an increased interest in EU affairs induces them to streamline procedures, invest in administrative resources and engage in networking with other actors, administrative empowerment is the result.

However, not all forms of empowerment are present for all regional parliaments. The Belgian regional parliaments, for example, have benefitted from strong institutional empowerment, as their 
right to participate in the EWS on an equal footing with the national parliament was enshrined directly in the European Treaties (cf. Bursens et al., 2015). The result is of course also policy empowerment and an increased political recognition by other actors as well as information empowerment, as they are forwarded all relevant documents directly by the Belgian Senate. By contrast, in the United Kingdom, there are no formal rules on the cooperation of regional and national parliaments under the EWS. One result of the absence of institutional empowerment translates into an absence of political empowerment and weak policy empowerment: the two chambers of the national parliament mention regional opinions, but only if they themselves decide to adopt a reasoned opinion. If they do not adopt one, then the regional opinions simply get blocked at that stage. However, all three regional parliaments benefit from better access to information albeit via their regional governments. In the case of Scotland, the EU administrative capacity of the parliament has been reinforced by additional staff (Author 2, this volume).

Author 6 (this volume) provide another example of how the EWS empowered regional parliaments: indirect empowerment. They explain how the Lisbon Treaty provisions and a judgment by the German Federal Constitutional Court emboldened the German regional parliaments, which had traditionally been largely excluded from EU affairs, to adopt new procedures for the scrutiny of regional governments and to invest in administrative resources.

\section{Understanding the different levels of empowerment and mobilization}

Edited volumes on regional parliaments in EU affairs, such as Abels and Eppler (2015) or Hrbek (2010), generally emphasize the different formal powers of regional parliaments in different member states. Author 2 (this volume) further showed that the EWS has empowered regional parliaments to different degrees and in different ways. In addition, there is also considerable cross-regional variation in the level of mobilization. For instance, 23 regional parliaments in the Subsidiarity Monitoring Network of the Committee of the Regions have so far never submitted a reasoned opinion (e.g. Author 3 this volume). What explains this variation?

In the introduction, Author 1 (this volume) hypothesized that five factors are the source of differentiated behavior and empowerment: Firstly, they argued that a high pre-existing formal strength as defined by the constitutional position of the assemblies would lead to a better deal in the national implementation of the EWS. Low powers under the EWS can in turn be seen as a disincentive for mobilization. Secondly, the presence of Eurosceptic parties at the regional level or a Eurosceptic public opinion can create pressures for active parliamentary scrutiny also by regional parliaments (e.g. Raunio, 2009). Thirdly, better staffed parliaments can be expected to be more active, as they have a greater capacity to process information and draft reasoned opinions 
(Högenauer et al., 2016). However, close executive-legislative cooperation or interparliamentary cooperation can have a similar 'enabling' effect and may allow regional parliaments to compensate for a lack of own resources (Castellà Andreau and Kölling, 2015; Miklin, 2015; Högenauer et al., 2016).

Author 2 (this volume) studied empowerment in the case of the EWS and showed that this depends largely on four factors: (1) Empowerment is likely to be particularly strong where formal provisions enshrine the new rights or regional parliaments. Going beyond this argument, it can be argued that (2) the willingness of national actors to agree to such rules depends on the prior constitutional strength of regional parliaments. In the Belgian case, for example, the exceptionally strong rights of the regions under the EWS are a direct result of pre-existing constitutional principles: Firstly, Belgium pursues a dual federal model, where policy competences are allocated as clearly as possible to the different regional and federal entities. Secondly, the principle of in foro interno, in foro externo means that the actor that is responsible for the policy domestically is also responsible for the policy in an international negotiation. As a result, if a policy is an exclusive regional competence in a Belgian setting, then regional parliaments (and not the national parliament) are responsible for scrutinizing external policy-making in that area (cf. Bursens et al., 2015; Högenauer et al., 2016). Inversely, in the British case, the UK government retained responsibility for the external representation of the country. The powers of regional governments do not benefit from a high degree of formalization and thus it is unsurprising that there is no formal agreement on the powers of regional parliaments either. In the German case, regional involvement in EU policy-making has been constitutionally defined, but traditionally the emphasis lay on regional governments and the German Upper House, which also represents regional governments. Thus, the emphasis on the Bundesrat in conjunction with the absence of institutional empowerment of regional parliaments is again in line with tradition. This links to another factor of Author 2 (this volume), whereby (3) the existence of second chambers that represent regional governments leads to a focus on governments rather than parliaments. Finally, in line with the hypothesis that resources matter, Author 2 argues that (4) good executivelegislative cooperation on subsidiarity scrutiny increases the chances of parliamentary empowerment.

Author 3's analysis of the reasoned opinions in the REGPEX database sheds lights on the source of different levels of activism (Author 3, this volume). Focusing only on those regional parliaments and executives with legislative powers that have already submitted opinions, Author 3 finds that the presence of supporting resources (e.g. a European Affairs Committee and/or staff dedicated to EU affairs) has a positive impact on the level of activity of the actor. Author 6's findings confirm this dynamic in the case of Germany. When the interest of the German regional parliaments in EU affairs increased, many invested in staff to increase their capacity for scrutiny. They also find that the 
differences in staffing have an impact on the ability of regional parliaments to scrutinize EU affairs (this volume). Furthermore, Author 3 (this volume) argues that a greater temporal distance of a proposal to the last regional election has a positive impact on activity, indicating that experience is a relevant factor. Finally, the number of regions in the member state has a negative impact on the level of activity, which could mean that the activity of one region allows others to free-ride or that networking between many regions requires too many resources. Interestingly, Author 3's study finds that the distinction between 'federal' and 'non-federal' states produces no significant effect and that, furthermore, the presence of Eurosceptic parties does not lead to great activism. This would suggest that two of our hypotheses do not matter in reality, although Author 3's distinction between federal and non-federal regions does not necessarily reflect 'constitutional strength'. For instance, the Austrian (federal) regions have arguably much fewer legislative powers than Scotland in the nonfederal UK. In the case of the use of mandates, Author 4 (this volume) finds, for example, that different constitutional settings and opportunity structures do, to some extent, explain crossnational differences in the use of mandates. Finally, Author 6 (this volume) find that the German Länder use interparliamentary networks to overcome resource discrepancy, such as the lack of legislative-executive cooperation or low staff resources in certain regions.

Finally, the analysis of parliamentary written questions on EU affairs in the cases of Scotland and Bavaria from 2012 to 2014 confirms Author 4' findings. Author 5 (this volume) shows that the mainstreaming of EU affairs, i.e. the decision to make sectoral committees responsible for the review of EU policies that fall into their policy domain, increases the proportion of MPs who show some interested in EU affairs in comparison to parliaments where a European Affairs Committee play a dominant role in the scrutiny process. However, despite the fact that a larger proportion of Scottish MPs asked at least one EU-related question per year, the overall level of interest in EU affairs was still lower in the Scottish case. On an individual level, Author 5 confirms that opposition MPs use this tool far more actively than government MPs, asking almost all of the EU-related questions (Author 5 this volume).

\section{A distinct role for regional parliaments?}

The final, but crucial question that this special issue seeks to address focuses on the role that regional parliaments can or do play in EU policy-making. The focus is in particular on three core functions, derived from the literature (Raunio 2011; Abels 2015a; Sprungk 2013): a legislative function, whereby regional parliaments try to shape EU policies, a scrutiny function, whereby they try to control the regional and/or European executive, and a networking function, which can be used to support the other two functions. The legislative function will most likely be the weakest function, as 
almost all formal powers of regional parliaments are focused on scrutiny. Formally, the only (and very weak) way to shape legislation is through the Committee of the Regions. However, the different functions are not mutually exclusive. The scrutiny function, in particular, can be used to try and shape policies and can thus take one a weak legislative function. For example, some parliaments, such as at the UK parliament, propose concrete amendments in some of their reasoned opinions.

Author 1 formulated three lines of inquiry in this regard. Firstly, they expected regional parliaments to be particularly concerned about the local and regional dimension of EU policies, for example, relating to the implementation of policies, as a large share of the implementation falls onto the regional level compared to the national level (Reutter 2015; Miklin 2015). On the individual level as well, MPs are likely to focus on these issues as they may have some electoral salience. This expectation is also fueled by the incentive structure in several member states: In Germany, Austria and Italy, for example, the regional governments are allowed to participate in the formulation of the national position on EU policies, whereas regional parliaments are largely relegated to controlling their governments and implementing measures (Abels 2015b; Nicolini 2015).

This also gives rise to a second hypothesis, whereby regional parliaments are expected to focus on their control functions, rather than policy-shaping functions. One question in that regard is what they are trying to control: policy-making or policy implementation? Another key question is how effective they are at controlling their governments: Saalfeld (2005) argues, for instance, that EU integration has not only eroded the legislative powers of national parliaments, but the information asymmetries between governments and parliaments have also weakened the ability of parliaments to exercise their scrutiny function.

Finally, one relatively under-researched question is the extent to which regional parliaments engage in inter-parliamentary cooperation and for what purpose? Existing studies generally describe the different fora of inter-parliamentary cooperation and their composition and powers. However, what is missing is a more profound analysis of the actual activities within these fora. Such an analysis is necessary if we seek to understand whether cooperation is oriented more towards the exchange of information, or towards the collective control of EU (or national/regional) institution, or maybe even towards the shaping of policies and thus a compensation for the loss of legislative powers.

These questions are analyzed in particular in the contributions of Author 4 (this volume) on mandates, Author 5 (this volume) on parliamentary questions as well as Author 7 (this volume) on the scrutiny of the Common Agricultural Policy by the Belgian Regions. Overall, the findings indicate that the ability of regional parliaments to exercise the control and legislative functions has been significantly reduced. 
Ideally, a parliament would do at least three things as part of its scrutiny function: It would constrain its government ex ante by giving it a clear mandate, it would control the execution of the mandate ex post by asking the government to report to a committee or the plenary and it would be able to access the necessary information to (a) understand the policy and its effects, and (b) know the true actions of its government (Saalfeld, 2000; Author 4, this volume). In this ideal case, the parliament would also be able to compensate for the loss of legislative competences, as a strong mandate would allow it to influence negotiations in the Council of Ministers via its government. National parliaments, in particular, could potentially 'legislate by proxy'.

Author 4 (this volume) analyzes the first element of this process, namely the ability of regions to mandate their governments. $\mathrm{S} /$ he includes both mandates that have a formal basis in the Constitution, and political mandates (opinions) that have no formal basis, but are regarded as politically binding by both the parliament and government. Overall, despite the fact that many regional parliaments underwent procedural reforms after the Lisbon Treaty, only few regional parliaments have the power to adopt mandates. Some of the cross-national differences in the use of mandates may be related to the interplay of institutional context and prevailing national models. Thus, one could argue that many Austrian regional parliaments have mandating strategies, because the Austrian national parliament also has such powers. Conversely, in the case of Belgium, neither the national nor the regional parliaments have mandating powers, and the way the regional governments coordinate and represent the national position would make a mandating system difficult to use in practice. In the German case, the national parliament - including the second chamber - has mandating powers, but the federal Basic Law prevents regional parliaments from mandating the activities of the regional governments in the German second chamber. As a result, only three regional parliaments adopted mandating strategies, which are arguably unconstitutional (but so far unchallenged). However, the considerable intra-state variation (e.g. between the six Austrian Länder that have a mandating system and the three that do not) is so far difficult to explain, due to a lack of detailed empirical data (ibid.). On the whole, her/his analysis of regional parliaments in Germany, the UK, Austria, Belgium, Italy and Spain suggests that very few have mandating powers. In addition, those that have such powers rarely use them, as the lack of resources prevents them from using information effectively to hold their governments to account. As a result, while 11 national parliaments act as policy-shapers today (Neuhold and Smith, 2015), regional parliaments have so far been unable to fulfill this role. Author 4 (this volume) concludes that most of them are at best weak to moderately strong watchdogs.

Author 5's analysis of written questions largely reinforces Author 4' findings on mandates. Questions are an important part of the control function: Firstly, they allow MPs to gather information on 
policies and on the positions of other actors. Secondly, MPs can use questions to make the government report on its activities, and can thus monitor the government. In addition, questions can fulfill a representative function, when MPs use them to enquire about local or regional issues (Martin, 2011). Finally, questions could be used to achieve the government's commitment to a certain negotiating position. In that case, they can allow MPs to play a (weak) policy-shaping role (Author 5 , this volume).

Overall, Author 5 (this volume) finds that the degree of Europeanization of parliamentary questions is low. In the Scottish case, only 1.5 percent of all written questions refer to EU affairs (4 percent in the Bavarian case). In the Scottish case, in particular, EU-related written questions primarily serve an information function: MPs ask for information about EU policies in general, about the position of the government, or about the plans of action of the government. However, none of the question was used to express criticism or to push the government in a certain direction. It is of course possible that MPs use the information later as 'ammunition' in debates with the government. However, written questions in themselves only serve a weak control function.

What is most interesting is that neither Bavarian nor Scottish MPs use written questions as a tool to control or shape the actual EU policy-making process. If one focuses on those questions that relate clearly to a specific stage of the policy-process, then $80-90$ percent of these focus on the implementation of EU policies. In other words, written questions in both regional parliaments gather very little information about EU negotiations or the coordination of the position of the member state. Instead, they focus predominantly on how the government plans to implement policies and the potential effects of EU policies. Unsurprisingly, the territorial focus of $70-80$ percent of EUrelated written questions lies on the regional or the sub-regional level. The rest of the questions focus either on specific non-territorial actors (e.g. on a company) or on the European level in general. Almost no questions consider the member state as a whole in relation to EU politics (Author 5 this volume).

Author $7 s^{\prime}$ indepth case study of the scrutiny of the reform of the Common Agricultural Policy by the Walloon and Flemish parliaments further confirm our conclusions (this volume). The interviews with regional parliamentarians revealed that Belgian regional MPs were skeptical about their chances of influencing the Council of Ministers. Instead of trying to influence the legislation, they thus focused on controlling their regional government and its plans for the implementation of the policy. In addition, MPs mostly used different types of questions and focused on information gathering. They thus acted as (weak) watchdogs, trying to monitor the government rather than to constrain it. 
Finally, Author 8 (this volume) provide one of the rare analyses of the activities of interparliamentary networks. They compare three cases of interparliamentary cooperation: Their first case is the Conference of European Legislative Assemblies (CALRE), within which regional parliaments try to influence EU politics. The Baltic Sea Parliamentary Conference (BSPC), which contains representatives from national and subnational parliaments from EU and non-EU states, the European Parliament as well as some interparliamentary associations, is their second case. Thirdly, the Interregional Parliamentary Council of the Grande Région (Luxembourg, Lorraine and Saarland) represents a case of interregional cooperation within the EU. Author 8 find that these interparliamentary associations all use the networking function to exercise a collective control function over executives. However, while regional parliaments seem to concentrate on 'ex post' control domestically (i.e. the monitoring of governments), these assemblies focus almost exclusively on 'ex ante' control, i.e. the attempt to shape policies by formulating demands. The findings also show that interregional organizations that are highly institutionalized tend to be more active. As 'institutionalization' comprises factors such as the formal powers of the organization and its resources, the explanation is similar to the explanation of the level of activity of individual parliaments.

Overall, the findings of this volume suggest that regional parliaments currently focus largely on their control function, but so far only exercise weak control. However, while regional parliaments struggle under a lack of resources, which prevents them from exploiting their existing powers more effectively, they have the potential to play a distinctive role in EU politics. Their focus lies clearly on the regional and sub-regional dimension of EU policies, and they fulfill thus a different representative function from national parliaments. In light of the fact that individual MPs seem to focus predominantly on implementation issues, regional parliaments could play a valuable role in debates about the feasibility and impact of future EU policies. Also, it seems that regional parliaments can play a more active policy-shaping role in the framework of well-institutionalized interparliamentary organizations.

\section{Conclusions}

In the field of parliamentary EU studies, research was so far dominated by a clear focus on the EU and the national level. While regional parliaments are clearly 'latecomers in the EU multi-level parliamentary system' (Abels, 2015a), they can nevertheless no longer be treated as 'quantités négligeables' (Reutter, 2015, 214). The recently upcoming body of literature on regional parliaments (cf. Abels \& Eppler, 2015; Boronska-Hryniewiecka, 2013, 2015; Hrbek, 2010; Schmitt et al., 2013; Vara-Arribas \& Högenauer, 2015) as well as the contributions in this volume illustrate, that they can no longer be neglected for several reasons. Firstly, there are empirical reasons as regional 
parliaments with legislative power have a formal role in the EU Treaty, and they have utilized the Lisbon Treaty provisions for a wave of reforms. By including these 74 regional parliaments, studies on the EU parliamentary system can increase the number of cases. Consequently, this can, secondly, help to refine models and concepts that try to identify factors that explain commonalities and variations. Thirdly, there are normative reasons. According to Ben Crum (2015) the 'demos-test' is key when it comes to deciding if and which regional parliaments should play a role in EU affairs. This would limit the number of regional parliaments only to a handful. Yet, for normative, democratic reasons one cannot overlook that the regional level has a strong position in federal states (such as Austria, Belgium and Germany) and increasingly also in regionalized and devolved states (such as Italy, Spain and the UK). If the development of multi-level parliamentarism should be a remedy to the infamous democratic deficit of the EU, then it is important to include the third level and its contribution to democratic legitimacy in empirical analysis and in conceptual developments. However, studying regional parliaments in EU affairs is even more demanding than studying their national 'big sisters': in addition to including insights from parliamentary and from Europeanization studies, also insights from regional and federal studies need to be taken into account (Abels, 2015a, 36-43). Against the background of the ongoing crises in the EU, future integration along the lines of a 'Europe with the Regions' (Swenden \& Bolleyer, 2014, 251) is one option that calls for the inclusion of a parliamentary dimension.

\section{References}

Abels, G. (2015a). Subnational Parliaments as 'Latecomers' in the EU Multi-Level Parliamentary System - Introduction'. In G. Abels \& A. Eppler (Eds.), Subnational Parliaments in an EU Multi-level Parliamentary System: Taking Stock of the Post-Lisbon Era (pp. 23-60). Innsbruck: Studienverlag.

Abels, G. (2015b). No Longer Losers: Reforming the Germany Länder Parliaments in EU Affairs. In G. Abels \& A. Eppler (Eds.), Subnational Parliaments in an EU Multi-level Parliamentary System: Taking Stock of the Post-Lisbon Era (pp. 193-209). Innsbruck: Studienverlag.

Abels G., \& Eppler. A. (Eds.) (2015). Subnational Parliaments in an EU Multi-level Parliamentary System: Taking Stock of the Post-Lisbon Era. Innsbruck: Studienverlag

Boronska-Hryniewiecka, K. (2013). Subnational Parliaments in EU Policy Control: explaining the variations across Europe', EUI Working Paper RSCAS 2013/38. Florence.

Boronska-Hryniewiecka, K. (2015). Differential Europeanization? Explaining the impact of the early warning system on subnational parliaments in Europe. European Political Science Review, doi: http://dx.doi.org/10.1017/S1755773915000375

Bursens P., Maes F., \& Vileyn, M. (2015). Belgian Assemblies in EU Policy-Making: The More Parliaments, the Less Participation in EU Affairs? In G. Abels \& A. Eppler (Eds.), Subnational 
Parliaments in an EU Multi-level Parliamentary System: Taking Stock of the Post-Lisbon Era (pp. 175192). Innsbruck: Studienverlag.

Castellà Andreu, J.-M., \& Kölling, M. (2015). Asymmetrical Involvement of Spanish Autonomous Parliaments in EU affairs. In G. Abels \& A. Eppler (Eds.), Subnational Parliaments in an EU Multi-level Parliamentary System: Taking Stock of the Post-Lisbon Era (pp. 269-285). Innsbruck: Studienverlag.

Cheneval, F. \& Schimmelfennig, F. (2013). The Case for Demoicracy in the European Union. Journal of Common Market Studies, 51, 334-350.

Crum, B. (2015). The Emergence of an EU 'Multilevel Parliamentary Field' - Is there a Role for Subnational Parliaments? In G. Abels \& A. Eppler (Eds.), Subnational Parliaments in an EU Multi-level Parliamentary System: Taking Stock of the Post-Lisbon Era (pp. 63-76). Innsbruck: Studienverlag.

Gattermann, K., Högenauer, A.-L., \& Huff A. (2015). Research Note: Studying a New Phase of Europeanization of National Parliaments, European Political Science, 15, 89-107.

Hefftler, C., \& Gattermann, K. (2015). Interparliamentary Cooperation in the European Union: Patterns, Problems and Potential. In C. Heffler, C. Neuhold, O. Rozenberg, \& J. Smith (Eds.), The Palgrave Handbook on National Parliaments and the European Union (pp. 94-115). Basingstoke: Palgrave Macmillan.

Högenauer, A.-L. (2015). The Scottish Parliament - An Active Player in a Multi-level European Union? In G. Abels \& A. Eppler (Eds.), Subnational Parliaments in an EU Multi-level Parliamentary System: Taking Stock of the Post-Lisbon Era (pp. 251-267). Innsbruck: Studienverlag.

Högenauer, A.-L., Neuhold, C., \& Christiansen, T. (2016). Parliamentary Administrations in the European Union. Basingstoke: Palgrave Macmillan.

Hrbek, R. (Ed.) (2010). Legislatures in Federal Systems and Multi-Level Governance. Nomos: BadenBaden.

Kiiver, P. (2012). The conduct of subsidiarity checks of EU legislative proposals by national parliaments: analysis, observations and practical recommendations. ERA Forum, 12, 535-547.

Martin, S. (2011). Parliamentary Questions, the Behaviour of Legislators and the Function of Legislatures: An introduction. Journal of Legislative Studies, 17), 259-270.

Miklin, E. (2015). Towards a More Active Role in EU Affairs: Austrian State Parliaments after Lisbon. In G. Abels \& A. Eppler (Eds.), Subnational Parliaments in an EU Multi-level Parliamentary System: Taking Stock of the Post-Lisbon Era (pp. 157-173). Innsbruck: Studienverlag.

Neuhold, C. \& Smith, J. (2015). Conclusion: From 'Latecomers' to 'Policy Shapers'? - The Role of National Parliaments in the 'Post-Lisbon' Union. In C. Hefftler, C. Neuhold, O. Rozenberg, \& J. Smith (Eds.), The Palgrave Handbook of National Parliaments in the EU (pp. 668-686). Basingstoke: Palgrave Macmillan.

Nicolini, M. (2015). The New Italian Framework for Regional Involvement in EU Affairs: Much Ado and Little Outcomes. In G. Abels \& A. Eppler (Eds.), Subnational Parliaments in an EU Multi-level Parliamentary System: Taking Stock of the Post-Lisbon Era (pp. 233-250). Innsbruck: Studienverlag. 
Nicolaïdis, K. (2013). European Demoicracy and its Crisis. Journal of Common Market Studies, 51, $351-$ 369.

Raunio, T. (2009). National Parliaments and European Integration: What We Know and Agenda for Future Research. Journal of Legislative Studies, 15, 317-334.

Raunio, T. (2011). The Gatekeepers of European Integration? The Functions of National Parliaments in the EU Political System. Journal of European Integration, 33, 303-321.

Reutter, W. (2015). The Quandary of Representation in Multilevel Systems and German Land Parliaments. In G. Abels \& A. Eppler (Eds.), Subnational Parliaments in an EU Multi-level Parliamentary System: Taking Stock of the Post-Lisbon Era (pp. 211-229). Innsbruck: Studienverlag.

Saalfeld, T. (2000). Members of Parliament and Governments in Western Europe: Agency Relations and Problems of Oversight. European Journal of Political Research, 37, 353-376.

Saalfeld, T. (2005). Deliberate delegation or abdication? Government backbenchers, ministers and European Union legislation. Journal of Legislative Studies, 11, 343-371.

Schmitt, P., Ruys, T., \& Marx, A. (2013). The Subsidiarity Early Warning System of the Lisbon Treatythe role of regional parliaments with legislative powers and other subnational authorities, Report, Brussels: Committee of the Regions.

Schneider, E., Rittberger, B., \& Wonka, A. (2014). Adapting to Europe? Regional MPs' Involvement in EU Affairs in Germany. Regional \& Federal Studies, 24, 407-427.

Sprungk, C. (2013). A New Type of Representative Democracy? Reconsidering the Role of National Parliaments in the European Union. Journal of European Integration, 35, 547-563.

Swenden, W., \& Bolleyer, N. (2014). Regional Mobilization in the 'New Europe': A Research Agenda. Regional and Federal Studies, 24, 249-262.

Vara Arribas, G. (2015). The Early Warning System in Motion: Comparing Different Practices in Subnational Parliaments. In G. Abels \& A. Eppler (Eds.), Subnational Parliaments in an EU Multi-level Parliamentary System: Taking Stock of the Post-Lisbon Era (pp. 127-143). Innsbruck: Studienverlag.

Vara Arribas, G., \& Högenauer, A.-L. (2015). Legislative Regions after Lisbon: A New Role for Regional Assemblies? In: C. Heffler, C. Neuhold, O. Rozenberg, \& J. Smith (Eds.), The Palgrave Handbook on National Parliaments and the European Union (pp. 133-149). Basingstoke: Palgrave Macmillan. 